Policy Commentary

\title{
Agricultural and Natural Resources Policies in Nepal: A Review of Formulation and Implementation Processes and Issues
}

\author{
Ganesh R Joshi ${ }^{\mathbf{a}^{*}}$, Binaya Joshi ${ }^{\mathrm{b}}$ \\ a. Former Secretary, Government of Nepal \\ b. Central Department of Environmental Science, Tribbuvan University, Nepal
}

Manuscript Received: August 24, $2021 \quad$ Final Revision: September 16, $2021 \quad$ Accepted: September 16, 2021

\begin{abstract}
The government of Nepal has made efforts to formulate and implement the agricultural sector policies since the 1960s. It has formulated dozens of policies and strategies in agriculture, forestry, agro-forestry, climate change, land use, poverty alleviation, irrigation, etc. Some of the policies seem to be targeted to specific groups and communities (poverty alleviation policy), to different sectors and commodities (forest, agriculture, poultry, coffee, etc.), and address international and national concerns and priorities (climate change policy, agrobiodiversity). This study aims to review the implementation of the policy provisions of major agricultural and natural resources policies, explore possible causes for it and suggest measures to effectively implement policy provisions in the future. We have reviewed seven agriculture policies for their provision and implementation and identified some common features and inadequacies. Our recommendations for policy reform include the practice of wider consideration, inter-policy coherence, sufficient institutional framework, periodic policy evaluation, improved accountability, and consideration for national Interest.
\end{abstract}

Keywords: agriculture, policy system, policy provision, reformation

* Corresponding author; G. R. Joshi (grjoshi20@hotmail.com), B. Joshi (joshibinaya84@gmail.com), CAuthor(s)

Published by Nepal Public Policy Review and peer-review under responsibility of Policy Research Institute Nepal. Licensed under CREATIVE-COMMONS license CC-BY-NC 4.0 (c) (i) (5) 


\section{Background}

Public policy is a combination of basic decisions, commitments, and actions made by those who hold authority or affect government decisions (MRSC, 2017). In other words, public policy also refers to the rules, regulations, and guidelines formulated by governments to solve problems that have an impact on society and the public. Public policy over the ages has been a major instrument in the hands of governments for bringing about social welfare and the well-being of the people. Through public policy, the government sets out its plans and programs for the people. The policy-making process weighs and balances public values.

Policy formulation is governed by Policy System. It is the overall institutional pattern within which policies are made, involves interrelationships among three elements: public policies, policy stakeholders, and policy environments.

Policy analysts, citizen groups/ civil societies, trade unions, political parties, governmental agencies

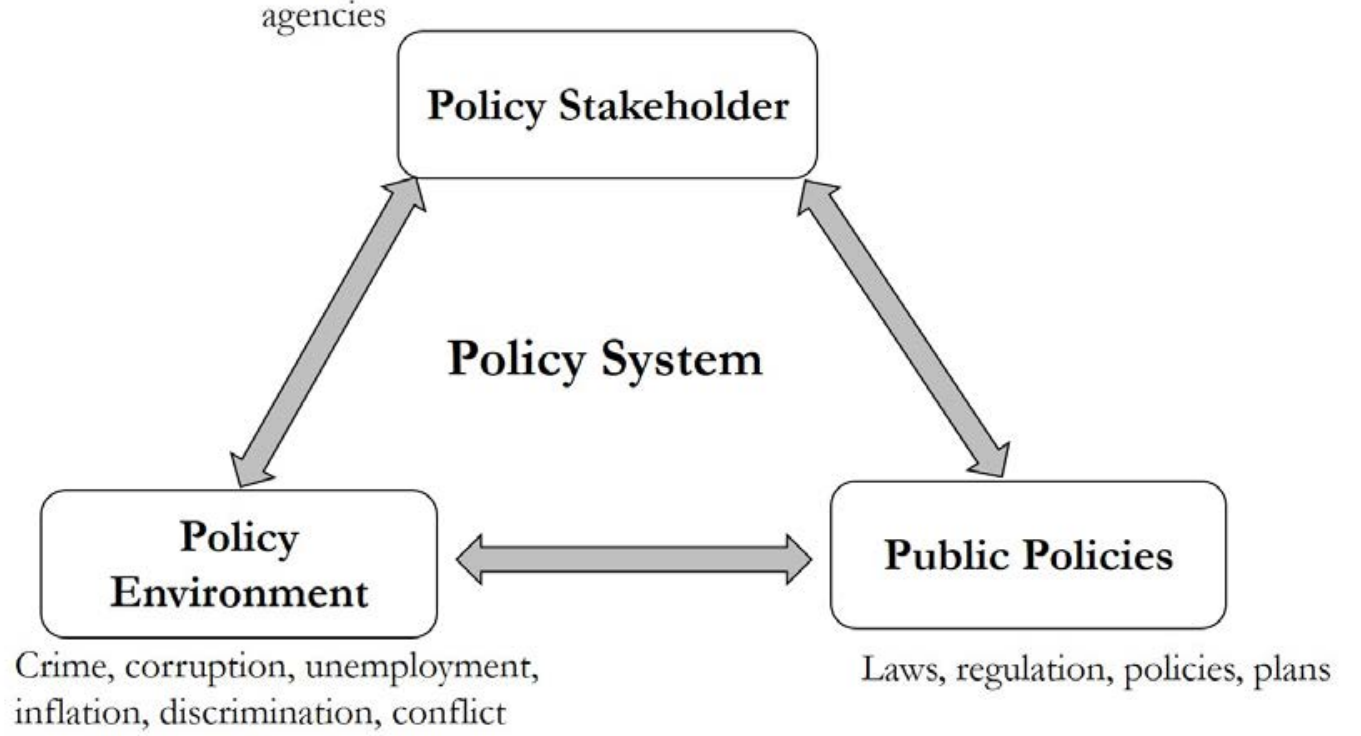

Figure 1. Public Policy System

Policies are formulated through a policy process that engages stakeholders in producing new or revised policies within a particular institutional context. The major stages of policy processes are policy formulation, implementation, and evaluation forming a cyclical pattern with a feedback loop from evaluation to formulation (Miller \& McTavish, 2014). The policies are legitimated by the legislature and implemented and evaluated with budgetary provision. An important element of the process is how policy decisions are taken.

\section{Context in Nepal}

The government of Nepal (GON) has made efforts to develop the agricultural sector and

\section{Page $\mid 213$}


policies since the 1960s. The GON has formulated dozens of policies and strategies in agriculture, forestry, agro-forestry, climate change, land use, poverty alleviation, irrigation, etc. for economic development, environment conservation, and poverty reduction. Under the agricultural sector, there are policies for different commodities, fertilizer, agri-business promotion, agrobiodiversity conservation, mechanization, rangeland management, etc. Agricultural policy is a critical element in determining the rate and pattern of economic growth and societal welfare. One set of policies such as investment in education, health, public infrastructures (transportation, irrigation) science and technology, trade, etc., have a broad impact on agricultural sector productivity, while other sets of policies affect particular agricultural commodities or techniques of production. These policies provide the framework and action plans necessary to achieve certain public goals and also provide the basis for promoting and enforcing certain rights and obligations to groups and individuals. It is argued that effective institutions with adequate investments can improve the living conditions of smallholder farmers and improve the incomes of the poor (Khanal et el.,2020).

Considering agricultural development as an interactive, integrated, interdependent, and multidimensional process, accelerated development of this sector is not possible through fragmented efforts. Therefore, for the performance-oriented growth of this sector, it was realized necessary to integrate the essential elements of agricultural development such as irrigation, technology, agricultural finance, improved seed, fertilizer, extension, physical infrastructures like roads, electrification, storage, agricultural marketing, and post-harvest operations through developing policies and strategies. Productivity drive can be enhanced if the factors of production and productivity are delivered as a package in an appropriate area and combination.

Some of the policies seem to be targeted to specific groups and communities (poverty alleviation policy), to different sectors/commodities (forest, agriculture, poultry, coffee, etc,), and address international/national concerns and priorities (climate change policy, agrobiodiversity). Such targeted policies usually are more effective in achieving the objective, they precisely aim to address needs and tailor the measures to achieve a better result. The policies use various kinds of instruments to achieve the result. Instruments are those economic variables that can be manipulated by policymakers and may include taxes, subsidies, regulations, payments for the delivery of a service, or even direct provision of services and products through the government. Policy instruments provide positive and negative incentives that are intended to affect the behavior of producers and consumers in such a way that the target variables are moving in the desired direction. While targeting has scope to improve the efficiency of agricultural policies, not all the issues can be addressed by a single policy.

This paper aims to review the implementation of the policy provisions of major agricultural and natural resources policies, explore possible causes for it and suggest measures to effectively implement policy provisions in the future.

\section{Major Policies and their Implementation Status}

\subsection{National Agricultural Policy 2004}

This Policy was formulated to support the implementation of the Agriculture Perspective Plan (APP) among others. The main objective of the policy is to create an enabling environment for agriculture-led rural development. The policy aimed to divide farmers into two groups - small 
and large and aims to provide more resources to the small farmers. The vision of the policy is to bring improvement in the living standard through sustainable agricultural development by transforming the subsistence agricultural system into a commercial and competitive agricultural system. It aims at achieving high and sustainable economic growth through a commercial agricultural system contributing to food security and poverty reduction, increased agricultural production and productivity, making agriculture competitive in regional and world markets with the commercial agricultural system, and conserving, promoting, and utilizing natural resources, environment and bio-diversity. Major policy provisions and their implementation status is summarized in table 1 below.

Table 1 Major National Agriculture Policy provisions and their implementation status

\begin{tabular}{|c|c|c|}
\hline Policy Provisions & Implementation status & Remarks \\
\hline $\begin{array}{l}\text { Discouraging the } \\
\text { transformation of fertile land } \\
\text { for non-agricultural uses } \\
\text { through adopting scientific } \\
\text { land use system. }\end{array}$ & $\begin{array}{l}\text { Although, land use policy has this } \\
\text { provision, but it is not implemented, } \\
\text { as conversion of agricultural land has } \\
\text { not stopped. }\end{array}$ & $\begin{array}{l}\text { Needs strong } \\
\text { commitments from } \\
\text { local governments and } \\
\text { stakeholders }\end{array}$ \\
\hline $\begin{array}{l}\text { Development and extension of } \\
\text { irrigation facilities, agriculture } \\
\text { roads, rural electrification and } \\
\text { appropriate technologies. } \\
\text { Intensive and wider use of } \\
\text { available technologies in the } \\
\text { areas with irrigation, roads and } \\
\text { electrification }\end{array}$ & $\begin{array}{l}\text { Pocket-package strategy of APP } \\
\text { implementation considered this provision }\end{array}$ & $\begin{array}{l}\text { Other sectoral } \\
\text { Ministries/ } \\
\text { Departments did not } \\
\text { focus their programs } \\
\text { for supporting agril. } \\
\text { sector }\end{array}$ \\
\hline $\begin{array}{l}\text { Special facilities for targeted } \\
\text { groups on small irrigation } \\
\text { infrastructures like tradle pump, } \\
\text { roar pump, sprinkler and drip } \\
\text { irrigation, water harvest pond } \\
\text { construction etc. }\end{array}$ & $\begin{array}{l}\text { This provision is being implemented by } \\
\text { MoFAGA(DoLI), MoALD (DoA) and } \\
\text { many (I) NGOs. }\end{array}$ & $\begin{array}{l}\text { Need to form strong } \\
\text { coordination } \\
\text { mechanism }\end{array}$ \\
\hline $\begin{array}{l}\text { Utilization of increasing } \\
\text { production and income } \\
\text { increasing possibilities in the } \\
\text { food deficit areas . Development } \\
\text { of food storage and } \\
\text { mobilization network with the } \\
\text { participation of local institution } \\
\text { if it has to be supplied from } \\
\text { outside areas. }\end{array}$ & $\begin{array}{l}\text { Special programs for increasing local food } \\
\text { production of indigenous crops such as } \\
\text { Foxtail millet, Barley, Finger millet, } \\
\text { Buckwheat, Chino etc) in food and } \\
\text { nutrition insecure high hills and hill } \\
\text { districts, and focus research in such crops } \\
\text { Local comparative advantage has not } \\
\text { been fully exploited. Limited storage } \\
\text { facilities developed, programs to attain } \\
\text { local food self-sufficiency initiated in a } \\
\text { limited scale in food deficit areas.. }\end{array}$ & $\begin{array}{l}\text { Appropriate } \\
\text { technological package } \\
\text { has to be developed, } \\
\text { effective coordination } \\
\text { with NFTC, local } \\
\text { bodies and MoALD } \\
\text { needed. }\end{array}$ \\
\hline
\end{tabular}


Expansion of livestock insurance and gradually initiating the insurance of poultry, selected crops seeds and HVCs.

Encourage and support to organic farming (through certification for export)
Expanded in commercial areas in a limited scale, $75 \%$ subsidy on insurance premium in order to attract entrepreneurs in agriculture and share the risks.

Supported organic farming (in the form of subsidies and technical backstopping) through annual program and budget (eg. IPM, FFS program). Technical Standard for Prodn \& Processing of Organic Products (2007), National Technical Standard for Organic Agriculture System 2008.
Yet to be expanded in commercial areas; working procedure to be developed to cover additional crops and commodities

Certification in Nepal is not yet institutionalized, integrate with National Trade Integration Strategy for the export of selected organic products

\subsection{Agro-business Promotion Policy, 2006}

The policy highlights diversification, commercialization, and promotion of the agriculture sector with private sector involvement in commercial farming. It emphasized that the living standard of the farmer would not improve unless the agriculture sector is transformed from subsistence level to commercial farming. The policy aims to reduce poverty by encouraging the production of market-oriented and competitive agro-products. It realizes the need of promoting internal and external markets. This policy was prepared in the spirit of National Agriculture Policy 2061 emphasizing business service centers' establishment for quality agriculture inputs and services. The partnership between the private sector and the Government has been emphasized for the export of quality goods. In the context of Nepal's entry into the WTO, developing the market network is its priority. The policy considers infrastructure development as a cornerstone for commercialization. The policy has envisaged the promotion of a partnership approach between the Government and the private sector. Major provisions and their implementation status is summarized in table 2 below.

Table 2 Some provisions of Agro-business Promotion policy provisions and their implementation status

$\begin{array}{ccc}\text { Policy Provisions } & \begin{array}{c}\text { Convergence/Implementation } \\ \text { status }\end{array} & \text { Remarks }\end{array}$

Establishment and development of Growth center based on geographic, economic, and technical potentiality.

Designation and demarcation of three types of production areas, namely commercial crop and commodity production area; organic and pesticide free production area; and agricultural products export area.
Commercial pockets yet to be developed as growth center. This has not been materialized so far.

The commercial production in certain commodities and location, organic production of selected commodities (like coffee, orthodox tea, spices) started and export (in limited scale) is taking place.
Common understanding and cooperation among other supportive ministries to MoALD for developing growth centers

The demarcation of three types of production area is yet to be implemented. 
Development of infrastructure (business service centres, markets and collection points, and rural roads and electricity) for postharvest, marketing and

processing.

Proposes for $75 \%$ tax redemption in the import of machineries and equipments (thresher, sprinkler, harvester, chilling van, cooling vat, milk processor etc) for 10 years.

Avail the rangeland on long term lease with the coordination of concerned authorities for livestock raising in the high hills.

Encourage the plantation of NTFPs in the public and other lands based on potentialities.

Proposes for $25 \%$ rebate on electricity cost for cold and frozen storage, cold chain, cold chamber and chilling vat and animal slaughterhouses for pvt entrepr. for 10 yrs from the date of establishment.

Promote agro-business by providing certification services for organically produced agril commodities for export.

Development of system for insurance of commercial crop production, livestock, markets, and agro-industries
Collection centers in nearby production pockets developed where there is road facility.

Some provisions are reflected in annual budget speech (for selected machineries and equipment)

Also mentioned in Rangeland Policy 2012, not implemented yet.

The community forestry and leasehold forestry groups have started NTFPs plantation but in a limited area.

Limited implementation (for selected enterprise) through annual budget speech

Technical Standard for Production and Processing of Organic Products and the MoALD s providing required services to the exporters.

The insurance system for livestock and other commercial crops/ commodities initiated with upto 75 percent subsidy on premium (announced in annual budget speech)
Devt of infrastructures

for climate resilient

agri-business need to be accelerated, other ministries should consider these aspects

MoALD pursue this matter with $\mathrm{MoF}$ before the annual budget preparation.

Need a coordinated effort with MoFE and

MoFAGA, Local govts.

MoFE, MoALD and MoFAGA, provincial govternment's need to work together.

\section{MoALD and FNCCI} pursue this matter with $\mathrm{MoF}$ before the annual budget.

The National Organic Certification Authority has not been established. Financial support for organic certification provisioned in budget speech.

Guidelines already prepared by MoALD.

\subsection{Climate Change Policy, 2011, first amend. 2019}

In order to adapt to and mitigate the impacts of climate change, and get the maximum benefit

\section{Page $\mid 217$}


from the climate change convention, CC policy was formulated. The vision of this policy is to save from the adverse impact of climate change considering climate justice, human development, and maintenance of prosperity through the adoption of the concept of environmental and sustainable development. It considered the importance of the sectors that are vulnerable to climate change and planned to enhance the climate adaptation and resilience capacity of local communities for optimum utilization of natural resources and their efficient management, adopt the low carbon development path by making socio-economic development climate change friendly and resilient, and develop institutional framework for its effective implementation. Major policy provisions and their implementation status is summarized in table 3 below.

Table 3 Some provisions of Climate Change Policy and their implementation status

\begin{tabular}{|c|c|c|}
\hline Policy Provisions & Implementation status & Remarks \\
\hline $\begin{array}{l}\text { Climate adaptation, } \\
\text { disaster and risk } \\
\text { reduction }\end{array}$ & $\begin{array}{l}\text { Different projects are in operation } \\
\text { to address NAPA priorities and } \\
\text { vulnerabilities such as NCCSP, } \\
\text { BCBRN, ASHA etc. }\end{array}$ & $\begin{array}{l}\text { Introduced CC budget code in } \\
2013 \text { to channel Climate } \\
\text { finance and track public } \\
\text { expenditure, DPs supporting } \\
\text { GoN to mainstream DRR intc } \\
\text { devt planning at national and } \\
\text { local levels. }\end{array}$ \\
\hline $\begin{array}{l}\text { Low carbon } \\
\text { development and } \\
\text { climate resilience }\end{array}$ & $\begin{array}{l}\text { Draft of NLCED strategy } \\
\text { formulated, Climate resilient } \\
\text { development planning tools } \\
\text { developed, renewable and } \\
\text { alternative energy technologies } \\
\text { promoted/expanded, REDD } \\
\text { strategy prepared (and involved in } \\
\text { carbon trade) }\end{array}$ & $\begin{array}{l}\text { Devt and adoption of Low } \\
\text { methane emission agricultural } \\
\text { technologies }\end{array}$ \\
\hline $\begin{array}{l}\text { Access to financial } \\
\text { resources and } \\
\text { utilization }\end{array}$ & $\begin{array}{l}\text { Establishment of Climate change } \\
\text { fund and Climate change center are } \\
\text { yet to be materialized. Managed the } \\
\text { funds available from different } \\
\text { sources on climate change, CDM } \\
\text { institutionalized and functional. }\end{array}$ & $\begin{array}{l}80 \% \text { climate finance to be } \\
\text { allocated to support local level } \\
\text { activities }\end{array}$ \\
\hline $\begin{array}{l}\text { Capacity building, } \\
\text { peoples' participation } \\
\text { and empowerment }\end{array}$ & $\begin{array}{l}\text { LAPAs prepared through a } \\
\text { participatory and inclusive process } \\
\text { and implemented at local level by } \\
\text { govt, NGOs and CBOs. }\end{array}$ & \\
\hline $\begin{array}{l}\text { Technology } \\
\text { development, transfer } \\
\text { and utilization }\end{array}$ & $\begin{array}{l}\text { NRREP channeling funds through } \\
\text { NREF for transfer of renewable } \\
\text { energy technologies, Scaling up } \\
\text { Renewable Energy Program, } \\
\text { NARC conducting agricultural } \\
\text { adaptation and resilient building } \\
\text { technologies. }\end{array}$ & $\begin{array}{l}\text { Many institutions involved for } \\
\text { sectoral technologies } \\
\text { development and transfer, a } \\
\text { central level mechanism } \\
\text { needed to identify gaps and } \\
\text { need of the technologies and } \\
\text { build synergies. }\end{array}$ \\
\hline
\end{tabular}

Page $\mid 218$ 
Establishment of CC

Fund and CC Center

for implementing

programs related to

CC adaptation and

resilience, and

developing and

utilizing technologies
This has not been established yet

\subsection{Irrigation Policy, 2014}

The vision of this policy is to avail sustainable and reliable year-round irrigation facilities to all the agricultural lands so as to contribute to agricultural productivity. This is important in the context of meeting the objectives of increasing agricultural production and reduction of poverty. The policy emphasizes implementing reservoir-based and inter-basin water transfer types of water sector strategy development and integrated water resources management. Further, it aims round the year irrigation facility through effective management of existing water resources; develop the institutional capacity of water users for sustainable management of existing systems; and enhance knowledge, skills, and institutional working capability of technical human resources, water users, and NGOs relating to the development of irrigation sector. The policy provisions related to other organizations and their implementation status are presented in table 4 below.

Table 4 Some provisions of Irrigation Policy and their implementation status

\begin{tabular}{cll}
\hline Policy Provisions & Implementation status & Remarks \\
\hline
\end{tabular}

Preparation of master plan at the national and district level

considering integrated development and management of river watershed in order to address challenges of irrigation sector

The GoN will declare irrigation available area as "irrigated area" and should get permission from the government for nonagricultural uses.

Based on the differences in geography and topography, consideration will be given for optimum utilization of technology, structure and water sources and studies will be carried out in this respect.
It will take some time to implement.

Some programs are ongoing: small and micro irrigation implemented by DOLIDAR and DOA, medium and large scales by the DOI. These are subsidized
Coordinate with MOEWRI, MOSTE, MOFE and provincial agri and forest related agencies.

Needs to be harmonized with Land use policy and collaboration needed with Local Govts and administration

STW program in Terai, micro and small irrigation in the hills and terai ongoing. Needs to have a coordination mechanism at the grass root level to avoid the duplication and optimize the potentiality. 
and supported by the government.

Supplementary irrigation development through rain water harvesting, reservoir development and conservation and utilization of ground water resources

Implementation of climate risk and disaster risk management programs and adaptation and mitigation programs to address climate change impacts

Working policy: Environment Protection and water quality management:

Public hearing, social auditing and minimization of adverse impacts from the irrigation project development.

Conservation of ponds, wetlands, springs available at the local level while developing irrigation schemes.

Each irrigation office will collaborate and manage irrigation with Priority package program of Dept of Agriculture where the water users are active and can provide year round irrigation
There are ongoing schemes for rainwater harvesting in rainfed areas and groundwater in Terai.

Peoples' embankment program to control the river and protect from floods (implemented by DOWRI)

This consideration is valid from the local users' perspective but adopted in limited areas.

This is not considered while developing infrastructures; need to coordinate with local govt./authorities.

A working mechanism at the Director General level exist between DOI and DOA. The delivery is not as expected. irrigation
Infrastructure devt, water utilization and efficiency mentioned in ADS.

These schemes need to be scaled up and business plan need to be developed in cooperation with MoALD, provincial ministries and local govts.

Coordinate with MoHA, DCCs and President Chure Conservation Committee (MoFE), local govt. Harmonize with Local Infra. Devt. Policy (2004).

Need to promote these measures also from transparency, accountability, and integrity.

DOI need to collaborate with DOA to make coordination mechanism effective and avail the water as per the reqt of the crops.

\subsection{National Land Use Policy, 2015}

This policy was formulated considering the growing concerns about the increasing fragmentation of fertile land and unplanned urbanization. The vision of this policy is to make optimum use of available Land and Land Resources (LLRs) in pursuit of sustainable social, economic, and ecological developments and prosperity of the country as well. This aims at ensuring the optimum use of land and control land fragmentation, helping establish a link between agricultural with industrial sectors. Land use policy 2015 of Nepal included classification of land in the number of zones (11 categories) based on suitability, preparation of federal landuse plan with priority for protection of agricultural land by land consolidation, and commercial farming. It also includes subsidizing tax for agricultural land to promote sustainable agriculture. 
Major policy provisions and their implementation status is summarized in table 5 below. Table 5 Some provisions of national Land Use Policy and their implementation status

\begin{tabular}{|c|c|c|}
\hline Policy Provisions & Implementation status & Remarks \\
\hline $\begin{array}{l}\text { Land use zoning - Land will be } \\
\text { classified into } 11 \text { different land use } \\
\text { zones } \\
\text { Working Policy: } \\
\text { Encourage to grow agriculture crops in } \\
\text { lands having potential/existing irrigation } \\
\text { facility while considering soil } \\
\text { conservation in the hills. }\end{array}$ & \multirow[t]{2}{*}{$\begin{array}{l}\text { Land Act } 8^{\text {th }} \text { amendment } \\
(2019) \text { (in collaboration } \\
\text { with other concerned } \\
\text { Ministries) focused on the } \\
\text { implementation part of } \\
\text { the land use plan. }\end{array}$} & \multirow[t]{2}{*}{$\begin{array}{l}\text { Effective coordination } \\
\text { and communication } \\
\text { among relevant govts } \\
\text { and agencies needed }\end{array}$} \\
\hline $\begin{array}{l}\text { Land Use Plan Prepare and use of Land } \\
\text { Use Plan at different levels }\end{array}$ & & \\
\hline $\begin{array}{l}\text { Ensure development works } \\
\text { implemented in accordance with land } \\
\text { use plan }\end{array}$ & $\begin{array}{l}\text { Classification of land } \\
\text { based on utilization } \\
\text { started }\end{array}$ & $\begin{array}{l}\text { Need to establish a } \\
\text { separate institution for } \\
\text { implementation. }\end{array}$ \\
\hline $\begin{array}{l}\text { Include productivity, environmental } \\
\text { conservation, social and economic } \\
\text { development, and poverty alleviation } \\
\text { considerations in land use plans }\end{array}$ & $\begin{array}{l}\text { Land use guidelines } \\
\text { revised }\end{array}$ & $\begin{array}{l}\text { Need to collaborate with } \\
\text { province and local levels } \\
\text { and concerned } \\
\text { ministries. }\end{array}$ \\
\hline
\end{tabular}

\subsection{Forest Policy, 2015}

The vision of this policy is to contribute to local and national prosperity through the sustainable management of forests, biodiversity, and watersheds. It aims to identify the forests that have the potentiality of increasing production and productivity for sustainable management.

The working policies under integrated management of watershed areas for increasing land productivity through protecting land and water include development and transfer of technology on low-cost soil and watershed protection and agroforestry system through action research and implementation of soil conservation program by harmonizing between forest and agricultural system for contributing to food production and food security are mentioned. Similarly, its provisions to create green employment and value addition by involving the private sector in forest development and expansion through forest enterprise promotion, product diversification; marketing; implement the mitigation and adaptation approaches for the negative impacts of climate change; and capacitate the management for good governance, inclusion, and social justice promotion in the forestry sector.

For the implementation of these provisions, these provisions have to be harmonized and make consistent with other sectoral and cross-cutting policies such as agriculture, industry,

\section{Page $\mid 221$}


trade/industry, poverty alleviation, climate change, etc. The implementation has not taken momentum as restructuring of the agricultural and forestry-related organization took place at different levels which created confusion about the roles and responsibilities. Hence, there needs role clarity and effective coordination to be maintained from the planning stage to implementation among three tiers of governments and multi-stakeholders involved in agriculture, forestry, and research and extension.

\subsection{National Agroforestry Policy, 2019}

This policy aims to contribute to national prosperity through the development, expansion, and commercialization of the agroforestry system. The objectives are to increase the production of agricultural, livestock, and forest products by increasing the productivity of the land and multipurpose use of the land; to conserve the environment and biological diversity by reducing pressure over the forest, to maintain quality, and to develop climate resilience ecosystem; to create opportunities for livelihood, employment and income generation along with food security of the local communities by widely promoting agroforestry; to contribute to the economy through commercialization and facilitation of investment opportunities in agroforestry, and to conduct study, research, and capacity enhancement in agroforestry subjects. Further, for its implementation, it demands to promote synergies with other policies such as agriculture, forestry, climate change, science and technology, climate change poverty alleviation, biodiversity, and many more. Further, this also requires to develop an institutional mechanism/framework at different tiers for coordination, communication, and collaboration.

\section{Why do our agricultural and natural resource policies fail to deliver targeted outcomes?}

As many policies have failed to get implemented and failed to generate desired policy outcomes even if they are implemented, the same applies to policies related to Agriculture and Natural Resources. It is well known that policy is a process that involves different actors, at the center of which are issues of power, social relations, and political influence. It is now widely accepted that policy reform for sustainable development is not achieved by adding more new public policies to the already impressive rosters, in the name of rural development and sustainable agriculture, forestry, or natural resources management. It is very important to know the governance in terms of the structures and processes that determine how policy is formulated and implemented. Weak governance within and between the governments, the private sector, and local communities results in bad policy or bad policy implementation, which in turn affects peoples' livelihood and the health of the natural resources. Moreover, policymaking is the result of a bargaining process among actors, who frequently have diverse and even opposing preferences and interests. The bargaining power of those actors differs, derived from a variety of sources such as the existing formal rules, informal norms, their ability to represent and mobilize other groups in society, or their control over resources (World Bank, 2017). The gap between policy on paper and implementation, in reality, seems to be one of the most serious challenges for development in the country. Let us look at the general features or tendencies in policy formulation and implementation in Nepal. 


\subsection{Consideration of only ideal situation}

A traditional approach is usually adopted, where possible states of the world are listed, given the set of possible choices, assigning a probability to each state, and calculating an expected outcome by considering costs and benefits. This works well in situations, where the choices are well-known and where uncertainty can be quantified as risk. However, public policy often takes place in complex domains where it is not possible to conceive of all the possible states of the world, much less to quantify probabilities and costs or benefits. This often leads to unintended consequences or failure in policy implementation. As per Muller (2020), the features of the public policies are - non-linear and emergent, do not settle in equilibria and hard to predict, evolve and coevolve, subject to cognitive biases, and they suffer from reactivity. Usually, the policy makers have the tendency to underestimate the complexity and challenge inherent in the process of policy making.

\subsection{Influence of interest groups}

Interest Groups are associations of individuals or organisations that on the basis of one or more shared concerns, attempt to influence public policy in their favour usually by lobbying members of the government. Interest groups seek to exert influence or pressure on government officials by various ways on key decision making issues in order to have policies that favour their members. There may be wide varieties of interests in agriculture, natural resources including land and forestry, trade and industry and climate governance etc. Interest Groups have been very visible putting pressure on centers of policy making either in the legislative or the executive body. They lobby with these bodies and advocate the policy provisions in their favor. Interest groups exert influence on the policy process from the stage of policy initiation, formulation to implementation. The positive aspect is that these groups help bring government closer to the people by making available to policy makers vital information that could improve their outcome of public policy (Akhakpe, 2014). An example can be cited in terms of influence of interest groups for the eighth amendment of the Land Act. This allowed the industries to relocate in any parts of the country by amending the provision of Land Act. The industries that were enjoying the land ceiling (by relaxing the provisions for industry) can now sell their valuable land and buy cheaper land in other parts of the country. This is against the spirit of land reform as they occupied land for operating industry and planning to sell or use for other purposes (than initially stated).

\subsection{Putting all what you have learnt or heard}

Most often, the policy makers or participants/stakeholders try to express and ask to document all the information what they have learnt or heard in the policy or considering their interest (without accounting others' concerns) in the policy making process. This sometimes undermines the ground reality, and needs and aspirations of the beneficiaries, to whom we intend to make policy. Thus, it tends to have inconsistencies and sometime overlap with other strategies and policies. In addition, there is tendency among experts, bureaucrats or even among politicians, that their views are "correct" and should be put in place. The policy making is a context specific, but often the policy makers borrow policy provisions from elsewhere in a national policy document which may not be feasible to implement as conditions may differ. This, though, gives a beauty to the policy document, but lacks practicality for implementation. 
The stakeholders/participants sometimes become reactive and formulate policies in response to an existing situation or a problem rather than on need-basis. Due to this tendency of formulating isolated policies, many policies and their provisions are in contradiction with each other and are shelved without any likelihood of implementation.

\subsection{Political instability and implementation}

Nepal has adopted many policies that are in line with the national needs and international agreements, but their implementation has been very weak. There is a rich set of documented policies for almost all sectors, but they have not been put into practice. Many a times, policy implementation depends on the individuals and therefore any change in the government usually leads to changes in, how a policy is interpreted and implemented. Nepal has undergone frequent changes in Government administration and the transfer of staff which has meant that institutional memory in the government is very limited. This has often hampered proper implementation of policies. Some of the policies (such as National land policy 2019 and Land use Policy 2015), though are considered important, but could not be implemented because that were not supported by any legislation, and Government instability primarily hindered discussions or passing of laws that would back up the implementation of those policies.

\subsection{Undermining inclusion in policy formulation}

One major/basic source of policy formulation is to consider the voice of the concerned stakeholders and needy groups. Inclusive processes are important to give all segments of society access to government decision making in order to better reflect their needs and aspirations, both in policy making and in service delivery. The inclusive processes increase awareness across the policy cycle and help to orient institutions in support of inclusive outcomes (Gent, 2017). Often, the process is supply-driven, inadequate consultation at different levels for securing commitment and consensus from stakeholders and failure to specify appropriate implementation arrangements, often leads to a failure on implementation of policies. But often, a very complicated framework is devised which could not owned by institutions and stakeholders at different levels leading to poor or no implementation.

\subsection{Politics shaping policies}

Some countries seem capable of sustaining policies over time, while in other countries, policies are frequently reversed or changed due to change in political and economic conditions. That may provide incentives for politicians and policy makers to deviate from established goaloriented policies and formulate the new ones. It is considered desirable to adapt policies to changing economic and political conditions and to formulate new ones or revise the existing policies. However, governments sometimes abuse the discretion to adapt policies by adopting opportunistic, one-sided policies that are closer to their own preferences or those of narrow constituencies. And, when the conditions are changed, the politicians make overly optimistic expectations and start a policy process. Usually, the politicians tend not to be held accountable for the outcomes of their policy initiatives - in the event of failure, the likelihood is that that they will have moved on or moved out. They may be easily attracted to the prospect of shortterm results. This can lead to the pushing through of policies as quickly as possible, rather than getting involved in the messy, prolonged, and frustrating details of how things might work out 
in practice (Hudson et al., 2019). In general, there is evidence to suggest that the political will necessary to drive long-term policy-making tends to dissipate over time (Norris and McCrae, 2013). Hence, the policy-makers including politicians are more likely to get credit for legislation that is passed than for implementation problems that have been avoided.

\subsection{Governance system}

Policies formulated at national level may face the challenge of ensuring some degree of consistency in delivery at subnational level, a process that is especially fraught where the subnational level has some separate degree of political authority (Norris et al. 2014). Sausman et al. (2016) mentioned the concept of "local universality" to describe the process whereby general rules, products, or guidelines are customized to fit into local contexts and enacted within practices. In Nepal, the policy making process was more centralized (top-down) and controlled before the federalism. Even now, the hangover persist and the provincial and local governments are reluctant to adopt the policies formulated by the federal government because sometimes they argue that they were not involved in the process. In addition, the policy provisions were put in place without proper assessment of the human resources capacity institutions at different levels and financial resources requirement. That also resulted in poor accountability, ownership, and implementation.

\section{Way Forward}

The lapses in the existing policy process and policy provisions and poor implementation discussed above suggest for some considerations to improve the exiting process and orientation, which can be as follows:

a) Wider Consideration: When developing policies and strategies, wider consultations have to be made with stakeholders at different levels to identify their needs and aspirations and ways to address them. This may reflect the reality on the ground. The consultation will ensure that every stakeholder understands the importance of policies, own it, and facilitate their implementation effectively.

b) Inter-policy Coherence: As many policies have some common themes and provisions, it is necessary to assess policy coherence from national to sub-national to local levels (vertically) and across line ministries and sectors (horizontally) to promote synergies and minimize tradeoffs. This will be useful to identify the common areas of focus or cross-cutting themes (and approaches adopted) while also improving tracking of the results and/or progress, identification of potential implementation partners, the actors involved, and maximizing local resources.

c) Sufficient Institutional Framework: Policy development should be backed by a strong institutional framework for its implementation. Many times policies are formulated without assessing the existing institutions and their capacity at different levels. Different governance systems have to be developed at federal, provincial, and local levels for collaboration and coordination required for its effective implementation. In addition, the capacity of the implementers should also be enhanced through education and training. The policy provisions should also be communicated to all the stakeholders timely at all levels.

d) Periodic Policy Evaluation: Once policies are developed and implemented, these are hardly assessed/evaluated in terms of their effectiveness and outcome. The research on several 
aspects of policies is essential to provide feedback to the implementers and other stakeholders so that the overall policy process (from agenda-setting to implementation) can be improved.

e) Increased Accountability: There is a tendency of policy implementors especially that of bureaucracy to start a new policy with the change in the political condition such as the change in government, without proper consideration of what was done before. Of course, corrections can be made in the ongoing policies based on their merits/evaluation, but a vacuum should not be created at once. The policymakers and implementers should be accountable for creating institutional memory and carry on further even in the context of change in government.

f) Consideration for National Interest: The policy-making process is not devoid of the influence of interest groups or unofficial government. Different groups lobby and advocate for their interest to be reflected in the policy provisions. Some groups seek benefits for very specific segments of society while others work for broader causes. In this context, the policymaking process should consider the national interest and welfare of the people at the center while developing any policy.

\section{References}

Akhakpe, I., (2014). Public policy, interest groups and sustainable development in Nigeria. Review of Public Administration and Management, 3(6), 36-48.,

Hudson, B., Hunter, D., \& Peckham, S., (2019). Policy failure and the policy implementation gap: Can policy support programs help?, Policy Design and Practice, 2(1), 1-14. DOI: $10.1080 / 25741292.2018 .1540378$

Khanal, N.R., Nepal, P., Zhang, Y., Nepal, G., Paudel, B., Liu. L., \& Rai, R. (2020). Policy provisions for agricultural development in Nepal: A review. Journal of Cleaner Production, 261, 121241. doi: 10.1016/j.jclepro.2020.121241

Miller, K. J., and Mc'Tavish, D. (2014). Making and managing public policy. Routledge

Ministry of Agriculture and Livestock Development (MoLAD). (2013). Collection of agricultural policies. Ministry of Agriculture and Livestock Development, Singhdurbar.

MRSC, (2017). Local government policy-making process. Municipal Research \& Services Center of Washington. https:// mrsc.org/getmedia/e46223b6-f3ac-4afb-b7d9b2362edf6890/Local-Government-Policy-Making-Process.pdf.aspx?ext=.pdf

Mueller B. (2020). Why public policies fail: Policymaking under complexity. EconomiA, 21 (2), 311-323. doi: 10.1016/j.econ.2019.11.002

Norris, E., Kidson, M., Bouchal, P., and Rutter, J. (2014). Doing them justice: Lessons from four cases of policy implementation. Institute for Government. https://www. instituteforgovernment.org.uk/sites/default/files/publications/Policy\%20Implementation $\% 20$ case $\% 20$ studies $\% 20$ report $\% 20-\% 20$ final.pdf

Norris, E., and McCrae, J. (2013). Policy that sticks: Preparing to govern for lasting change. London: Institute for Government. https:/ /www.instituteforgovernment.org.uk/ sites/default/files/publications/Policy $\% 20$ that $\% 20$ sticks $\% 20$ final_0.pdf

Sausman, C., Oborn, E., and Barrett, M. (2016). Policy translation through localisation: implementing national policy in the UK. Policy \& Politics, 44 (4), 563-589. doi: 10.1 332/030557315X14298807527143. 
van Gent, S. (2017). Beyond buzzwords: What is "inclusive development". INCLUDE. https://includeplatform.net/wp-content/uploads/2017/09/Beyond-buzzwords.pdf

World Bank. (2017). World development report 2017. World Bank. https://www.worldbank. org/en/publication/wdr2017

\section{Author's Short Bio}

\section{Ganesh Raj Joshi}

Ganesh Raj Joshi obtained his $\mathrm{PhD}$ degree with specialization in Resource Economics and Policy from UPLB Philippines. He is a former Secretary, who worked in different ministries of Government of Nepal such as forests and soil conservation, environment, tourism, agriculture, and defense. Dr. Joshi has completed his Post-doctoral research as a Research fellow of Alexander von Humboldt Foundation Germany. He is a Visiting Professor (Environmental Science) in TU and Chair of the Center for Green Economy Develepment Nepal. Dr. Joshi contributed as a Lead Author to Options for Governance Chapter in IPBES Asia Paicific Regional Assessment on Biodiversity and Ecosystem Services and as an Expert in the Scoping of Nexus (Food-Biodiversity-Energy-Water-Health) and Transformative Change Assessments. He has published over 3 dozen papers in the form of book, book chapters, journal article and seminar proceeding.

\section{Binaya Joshi}

Binaya Joshi completed his Master's degree in Environmental Science from TU Nepal. He worked as a Senior Climate Change Officer in the Third National Communication Project and National Climate Change Support Program implemented by the Ministry of Forests and Environment. He has published half dozen papers in the form of journal article, book chapter and workshop proceeding. Mr. Joshi is pursuing PhD in Environmental Science from TU Nepal. 